\title{
Læge søkes
}

Annonsering av ledige legestillinger er en viktig oppgave for Tidsskriftet. Den første stillingsannonsen sto på trykk så tidlig som i nr. 3/1883, den gang det var få offentlige legestillinger. Vi presenterer her et lite utdrag av stillingsannonser fra 1925 (Tidsskr Nor Lægeforen 1925; 45: 393-4). Legg merke til likheter - og ulikheteri lønns- og arbeidsvilkår.

\section{MEDDELELSER FRA DEN NORSKE LÆGEFORENINGS BUREAU OG SEKRETARIAT \\ Ved Jorgen H. Berner generalsekretær}

\begin{tabular}{l|l|l}
\hline \hline Nr. 7 & Onsdag den 1ste april 1925 & 32te aarg. \\
\hline
\end{tabular}

\section{Officielle meddelelser, ledige embeder og lægestillinger ved sykehus o. lign.}

Ledige distriktslægestillinger. D i s trikts 1 æg e s t 111 ing e n i Børs a distrikt, som omfatter herrederne Børsa, Børseskogn, Buvik og Byneset i Sør-Trøndelag fylke, er ledig fra 15de mai. Det er spørsmaal oppe om at utskille Byneset herred fra distriktet. Spørsmaalet er endnu ikke avgjort.

Aarlig løn 4500 kr. med tre alderstillæg à 300 kr. efter henholdsvis 3, 6 og 9 aars tjeneste. Dertil statens til enhver tid [etc. som for M a a $1 \mathrm{~s} \mathrm{e} 1 \mathrm{v}$ lægedistrikt i nr. 1 for 1925].

Der er kommunal lægebolig i Børsa med 1 maal have. Leien er for tiden $1000 \mathrm{kr}$.

Søknad bør gjennem vedkommende overøvrighet (fylkesmanden) være indsendt til Socialdepartementet inden 6 uker fra 12te mars.

Distriktslægestillingen i Bud distrikt, som omfatter herrederne Bud, Hustad, Nord-Aukra, Sør-Aukra og Fræna i Møre fylke, blir ledig fra ca. 1ste juni d. a.

Aarlig løn er $6000 \mathrm{kr}$. med tre alderstillæg à $300 \mathrm{kr}$. efter henholdsvis 3,6 og 9 aars tjeneste og to ekstraordinære tillæg à $500 \mathrm{kr}$. efter 3 og 6 aars tjeneste i distriktet. Dertil statens til enhver tid (etc. som for M a a l s e lv lægedistrikt i nr. 1 for 1925).

Av hensyn til mulig omregulering av disktriktet tages nødvendig forbehold om forandring av løn $\mathrm{m}$. $\mathrm{v}$.

Som bosted er fastsat Harøysund, hvor der er kommunal lægebolig. Leien er for tiden $1000 \mathrm{kr}$. pr. aar.

Søknad bør gjennem vedkommende overøvrighet (fylkesmanden) være indsendt til Socialdepartementet inden 6 uker fra 24de mars.

Distriktslægestillingen i S a 1 a n g e n, se nr. 5, utl. 6 uker fra 23 de februar. - I La vi k, se nr. 4, utl. 6 uker fra 9de februar.
O ply s n inger om de fleste ledige embeder, distrikter og stadslægeposter faaes i bureauet.

Iste-amanuensisposten ved Universitetets farmakologiske institut er ledig fra 1ste september 1925. Posten ønskes besat med en læge. Amanuensen ansættes med pligt til i den utstrækning, som bestyreren maatte finde nødvendig, at bistaa institutets bestyrer med undervisningen i farmakologi $\mathrm{m}$. v. og med de undersøkelser som foregaar ved institutet. Daglig arbeidstid 6 timer, leilighetsvis mere. Den aarlige løn er $5000 \mathrm{kr}$. med 6 alderstillæg à $500 \mathrm{kr}$. efter 3, 6, 9, 12, 15 og 18 aar. I lønnen fragaar indskud i Statens pensionskasse, for tiden 10 pct.

Ansættelsen sker forøvrig med pligt til at rette sig efter den instruks, som maatte bli utfærdiget for stillingen, samt med pligt til at finde sig i den ordning, som er eller blir truffet $\mathrm{m}$. h. t. pension og aldersgrænse.

Ansøkninger sendes Det akademiske kollegium inden 1ste mai d. a.

Sykehuslægepost i Harstad. Stillingen som sykehuslæge ved Harstad og Troms fylkes sykehus i Harstad er ledig og ønskes besat med en kirurgisk utdannet mand. Den faste løn er $4000 \mathrm{kr}$. pr. aar. Hertil kommer operationshonorar efter Lægeforeningens regulativ. Desuten vil der være anledning til at drive privat praksis i Harstad og omegn. Den ansættendes læge tilsikres løn i 3 maaneder under sygdom og 4 ukers ferie med fri vikar. Gjensidig opsigelsesfrist 3 maaneder.

Ansøkninger med bekræftende attestavskrifter indsendes hertil inden 6 uker fra idag.

Troms fylke den 18de mars $1925 . \quad$ Backe. 